\title{
NARrar O TRAUMA - A QUESTÃo dOS TESTEMUNHOS DE CATÁSTROFES HISTÓRICAS
}

\author{
Márcio Seligmann-Silva*
}

\section{Resumo}

O trabalho propõe uma reflexão sobre algumas das características do gesto testemunhal enfatizando as aporias que o marcam. Partindo da idéia de que o testemunho de certo modo só existe sob o signo de seu colapso e de sua impossibilidade, o texto enfatiza os dilemas nascidos da confluência entre a tarefa individual da narrativa do trauma e de sua componente coletiva. Nas "catástrofes históricas", como nos genocídios ou nas perseguições violentas em massa de determinadas parcelas da população, a memória do trauma é sempre uma busca de compromisso entre o trabalho de memória individual e outro construído pela sociedade. O testemunho é analisado como parte de uma complexa "política da memória”.

Palavras-chave: testemunho; memória do trauma; trauma; política da memória

\section{Abstract}

Narrating trauma - Testimonies of Historical CATASTROPHeS

The text carries out a reflection about some of the main issues concerning the gesture of testimony, highlighting the apories of witnessing. Departing from the idea that testimony only exists under the sign of its collapse and impossibility, the essay stresses the dilemmas raised from the convergence between the individual task of the trauma storytelling and its collective component. In historical catastrophes, as in the cases of genocides or violent mass persecutions of particular groups of people, the memory of the trauma is always a search for a compromise between the individual memory work and another, more collective. The testimony is analyzed as a part of a complex "politics of memory".

Keywords: testimony; trauma memory; trauma; politics of memory

* Professor livre-docente de Teoria Literária na Universidade de Campinas (UNICAMP) e pesquisador do CNPq. 
Parler, écrire, est, pour le déporté qui revient, un besoin aussi immédiat et aussi fort que son besoin de calcium, de sucre, de soleil, de viande, de sommeil, de silence.

Il n'est pas vrai qu'il peut se taire et oublier. Il faut d'abord qu'il se souvienne. Il faut qu'il explique, qu'il raconte, qu'il domine ce monde dont il fut la victime. Georges Perec (citado em Levi, 2005: 15)

Estas palavras de Perec nos lançam sem mais no coração da cena do testemunho. Antes de mais nada, vemos aqui a necessidade absoluta do testemunho. Ele se apresenta como condição de sobrevivência. O próprio Primo Levi (1988) expressou este fato no prefácio de $E$ isto um homem. Vale a pena voltarmos a estas palavras de Levi porque ele acrescenta a esta idéia de necessidade de testemunhar outro dado fundamental, a saber, a sua implícita dialogicidade: "A necessidade de contar 'aos outros', de tornar 'os outros' participantes, alcançou entre nós, antes e depois da libertação, caráter de impulso imediato e violento, até o ponto de competir com outras necessidades elementares" (Levi, 1988: 7). Seguindo estas palavras, podemos caracterizar, portanto, o testemunho como uma atividade elementar, no sentido de que dela depende a sobrevida daquele que volta do Lager (campo de concentração) ou de outra situação radical de violência que implica esta necessidade, ou seja, que desencadeia esta carência absoluta de narrar. Levi nesta passagem coloca as expressões "aos outros" e "os outros" entre aspas. Este destaque indica tanto o sentimento de que entre o sobrevivente e "os outros" existia uma barreira, uma carapaça, que isolava aquele da vivência com seus demais companheiros de humanidade, como também a conseqüente dificuldade prevista desta cena narrativa. Sabemos que dentre os sonhos obsessivos dos sobreviventes consta em primeiro lugar aquele em que eles se viam narrando suas histórias, após retornar ao lar. Mas o próprio Levi também narrou uma versão reveladora deste sonho, que ficou conhecida, na qual as pessoas ao ouvirem sua narrativa se retiravam do recinto deixando-o a sós com as suas palavras. A outridade do sobrevivente é vista aí como insuperável. A narrativa teria, portanto, dentre os motivos que a tornavam elementar e absolutamente necessária, este desafio de estabelecer uma ponte com "os outros", de conseguir resgatar o sobrevivente do sítio da outridade, de romper com os muros do Lager. A narrativa seria a picareta que poderia ajudar a derrubar este muro. A circulação das imagens do campo de concentração que se inscreveram como uma queimadura na memória do sobrevivente, na medida em que são aos poucos traduzidas, Über-Setzte, transpostas, para "os outros", permite que o sobrevivente inicie seu trabalho de religamento ao mundo, de reconstrução da sua casa. Narrar o trauma, portanto, tem em primeiro lugar este sentido primário de desejo de renascer. 
Gostaria de pensar, neste espaço, características deste gesto testemunhal enfatizando algumas das aporias que o marcam. A cena testemunhal não é de modo algum estranha aos profissionais da área de psicologia e decerto muito do que vou apresentar é bastante familiar, Heimlich, a vocês. Em certo sentido podemos ver a cena psicanalítica elementar, ou seja, o paciente diante de seu analista, como uma cena testemunhal. Trata-se, mutatis mutandis, de um sobrevivente buscando a atenção e escuta de um outro, tendo em vista a construção de um mundo menos Unheimlich ${ }^{1}$. Isto sem contar a centralidade da noção de trauma em Freud e na história da psicanálise, noção cuja história não trato aqui, mas é pressuposta, tendo em vista sua importância vital para se entender a questão da narrativa do trauma. Visando um local de compromisso entre esta cena familiar a vocês e abordagens mais históricas ou filosóficas, e sem perder de vista um possível diálogo, decidi enfatizar algumas das problemáticas nascidas da confluência entre a tarefa individual da narrativa do trauma e de sua componente coletiva. Daí a ênfase no título desta conferência na expressão "catástrofes históricas”. Nestas situações, como nos genocídios ou nas perseguições violentas em massa de determinadas parcelas da população, a memória do trauma é sempre uma busca de compromisso entre o trabalho de memória individual e outro construído pela sociedade. Aqui a já em si extremamente complexa tarefa de narrar o trauma adquire mais uma série de determinantes que não podem ser desprezados mesmo quando nos interessamos em primeiro plano pelas vítimas individuais. No que segue apresentarei em primeiro lugar alguns aspectos da mencionada dificuldade de se testemunhar. Veremos que o testemunho de certo modo só existe sob o signo de seu colapso e de sua impossibilidade. No segundo passo tratarei especificamente da questão da política da memória: primeiro introduzindo algumas definiçôes importantes para se entender o conceito de memória, depois tratando do tema da memória como uma política.

\section{NARRAR O INENARRÁVEL}

Dori Laub (1995), em um ensaio importante sobre o tema do testemunho da Shoah, dedicou especial atenção para a questão da "impossibilidade de narração" e formulou a idéia que o Holocausto foi "um evento sem testemunha" (Laub, 1995: 65). Neste trabalho ele destacou a impossibilidade daquele que esteve no Lager (o que se passou com o próprio Laub quando criança) de ter condiçóes de se afastar de um evento tão contaminante para poder gerar um testemunho lúcido e íntegro. $\mathrm{O}$ próprio grau de violência impediu que o testemunho pudesse ocorrer. Sem testemunho, evidentemente, não se constitui a figura da testemunha. Para ele 
a principal tarefa que coube aos sobreviventes foi a de construir a posteriori este testemunho. Esta tese de Laub me parece correta, mas deve ser vista cum grano salis. Ela gerou alguns mal entendidos, do tipo daqueles que a partir daí negam a importância dos testemunhos. O objetivo de Laub era evidentemente o oposto.

Primo Levi também destacou em diversas oportunidades esta impossibilidade do testemunho. Ele afirmava que aqueles que testemunharam foram apenas os que justamente conseguiram se manter a uma certa distância do evento, não foram totalmente levados por ele como o que ocorreu antes de mais nada com a maioria dos que passaram pelos campos e morreram, mas também com aqueles que eram denominados de Musulmänner dentro do jargão do campo, ou seja, aqueles que haviam sido totalmente destruídos em sua capacidade de resistir. Os que ocuparam algum local na hierarquia do campo, quer por conta de suas relações políticas ou por causa de seu conhecimento técnico (o caso do próprio químico Levi), estes puderam testemunhar, mesmo que não de forma integral, já que a distância deles também implicou uma visão atenuada dos fatos. Para Levi não se pode falar, com Laub, que não existiu o testemunho no Lager, mas antes que este testemunho foi parcial, limitado. Giorgio Agamben (1998) deriva das palavras de Levi algo semelhante ao que Laub afirmara. Isto, a meu ver, não corresponde aos textos de Levi. Para Agamben apenas os Musulmänner poderiam ser as testemunhas do campo, mas Levi nunca afirmou isto. $\mathrm{Na}$ introdução do volume $\mathrm{Os}$ afogados e os sobreviventes (Levi, 1990) ele apenas aponta para as limitaçôes do testemunho, como lemos na famosa frase: "a história do Lager foi escrita quase exclusivamente por aqueles que, como eu próprio, não tatearam seu fundo. Quem o fez não voltou, ou então sua capacidade de observação ficou paralisada pelo sofrimento e pela incompreensão" (Levi, 1990: 5). Mas mesmo para ele, membro deste grupo de paradoxais "privilegiados" dentro do inferno, a realidade do campo permaneceu como uma cripta (lembrando da expressão de Nicolas Abraham e Maria Torok, 1995), cripta esta que suas palavras atingiram com força, mas nunca conseguiram quebrar, o que talvez esteja na origem do próprio suicídio de Primo Levi.

No seu É isto um homem, de 1947, ele escrevera o seguinte com relação a este elemento encriptado da realidade do Lager: "Parecia impossível que existisse realmente um mundo e um tempo, a não ser nosso mundo de lama e nosso tempo estéril e estagnado, para o qual já não conseguíamos imaginar um fim" (Levi, 1988: 119). Lembremos também de outra passagem chave do mesmo livro: "Hoje - neste hoje verdadeiro, enquanto estou sentado frente a uma mesa, escrevendo hoje eu mesmo não estou certo de que esses fatos tenham realmente acontecido" (Idem: 105). Nesta passagem vemos dois momentos exemplares do testemunho: 
em primeiro lugar ele se dá sempre no presente. Na situação testemunhal o tempo passado é tempo presente (Mais um paralelo, aliás, com a cena psicanalítica e sabemos que Freud buscou várias metáforas ao longo de sua vida, como a da câmara fotográfica, um campo geológico e o bloco mágico, para exprimir este elemento paradoxal da temporalidade psíquica concentrada em um mesmo topos.). Mais especificamente, o trauma é caracterizado por ser uma memória de um passado que não passa. $\mathrm{O}$ trauma mostra-se, portanto, como o fato psicanalítico prototípico no que concerne à sua estrutura temporal. Levi diz que neste hoje da sua escritura ele não está certo se os fatos (do Lager) de fato aconteceram. Este teor de irrealidade é sabidamente característico quando se trata da percepção da memória do trauma. Mas, para o sobrevivente, esta "irrealidade" da cena encriptada desconstrói o próprio teor de realidade do restante do mundo 2 .

Hélène Piralian (2000), psicanalista de origem armênia, refletiu sobre esta questão ao tratar do genocídio armênio e sobre a questão da sua representação. Para ela a simbolização do evento implica a "(re)construção de um espaço simbólico de vida" (Piralian, 2000: 21). Esta simbolização deve gerar um retemporalização do fato antes embalsamado. Ele adenda, assim, ao fluxo dos demais fatos da vida. Piralian fala também, e de modo muito feliz, de uma tridimensionalidade advinda da simbolização. Ao invés da imagem calcada e decalcada, chata, advinda do choque traumático, a cena simbolizada adquire tridimensionalidade. A linearidade da narrativa, suas repetições, a construção de metáforas, tudo trabalha no sentido de dar esta nova dimensão aos fatos antes enterrados. Conquistar esta nova dimensão equivale a conseguir sair da posição do sobrevivente para voltar à vida. Significa ir da sobre-vida à vida. É claro que nunca a simbolização é integral e nunca esta introjeção é completa. Falando na língua da melancolia, podemos pensar que algo da cena traumática sempre permanece incorporado, como um corpo estranho, dentro do sobrevivente. $\mathrm{Na}$ cena do trabalho do trauma nunca podemos contar com uma introjeção absoluta. Esta cena nos ensina a sermos menos ambiciosos ou idealistas em nossos objetivos terapêuticos. Para o sobrevivente sempre restará este estranhamento do mundo advindo do fato de ele ter morado como que "do outro lado" do campo simbólico.

Este estranhamento está intimamente vinculado ao tema da irrealidade dos fatos vividos e da conseqüente inverossimilhança dos mesmos. Este constitui um topos importante das narrativas do trauma. O sobrevivente, como o tradutor, está submetido a um duplo vínculo. Enquanto aquele que traduz deve se submeter, ao mesmo tempo, sem esperanças de uma trégua, à ditadura da língua que traduz e a da língua para qual está traduzindo, do mesmo modo o sobrevivente no caso da Shoah tenta (sem sucesso) conciliar as regras de verossimilhança do universo 
concentracionário com as do "nosso mundo". O Levi que sonha com seu público ouvinte que o abandona já previa a sensação de inverossimilhança gerada pelos fatos que narraria e a conseqüente acusação de mentiroso que o esperava. Robert Antelme (1957), em seu testemunho sobre sua experiência nos campos alemães, também expressou esta angústia que está na base da pulsão testemunhal.

Há dois anos, durante os primeiros dias que sucederam ao nosso retorno, estávamos todos, eu creio, tomados por um delírio. Nós queríamos falar, finalmente ser ouvidos. Diziam-nos que a nossa aparência física era suficientemente eloqüente por ela mesma. Mas nós justamente voltávamos, trazíamos conosco nossa memória, nossa experiência totalmente viva e sentíamos um desejo frenético de a contar tal qual. E desde os primeiros dias, no entanto, parecia-nos impossível preencher a distância que descobrimos entre a linguagem de que dispúnhamos e essa experiência que, em sua maior parte, nos ocupávamos ainda em perceber nos nossos corpos. Como nos resignar a não tentar explicar como havíamos chegado lá? Nós ainda estávamos lá. E, no entanto, era impossível. Mal começávamos a contar e sufocávamos. A nós mesmos, aquilo que tínhamos a dizer começava então a parecer inimaginável. Essa desproporção entre a experiência que havíamos vivido e a narração que era possível fazer dela não fez mais que se confirmar em seguida. Nós nos defrontávamos, portanto, com uma dessas realidades que nos levam a dizer que elas ultrapassam a imaginação. Ficou claro então que seria apenas por meio da escolha, ou seja, ainda pela imaginação, que poderíamos tentar dizer algo delas (Antelme, 1957: 9)³.

É essencial nos determos um pouco nesta conclusão que Antelme extrai do dilema da testemunha. A imaginação apresenta-se a ele como o meio para enfrentar a crise do testemunho. Crise que, como vimos, tem inúmeras origens: a incapacidade de se testemunhar, a própria incapacidade de se imaginar o Lager, o elemento inverossímil daquela realidade ao lado da imperativa e vital necessidade de se testemunhar, como meio de sobrevivência. A imaginação é chamada como arma que deve vir em auxílio do simbólico para enfrentar o buraco negro do real do trauma. O trauma encontra na imaginação um meio para sua narração. A literatura é chamada diante do trauma para prestar-lhe serviço. Et pour cause, se dermos uma pequena olhada sobre a história da literatura e das artes veremos que os serviços que elas têm prestado à humanidade e seus complexos traumáticos não é desprezível. Da Ilíada a Os sertôes, de Édipo Rei (Sófocles, [500 BC.] 1982) à Guernica (Picasso, 1937), de Hamlet (Shakespeare, [1602] 1936) ao teatro pósShoah de um Beckett, podemos ver que o trabalho de (tentativa) introjeção da cena traumática praticamente se confunde com a história da arte e da literatura. A 
teoria freudiana da tragédia como ritual de exorcismo do assassinato do pai pela horda primeva é apenas uma das inúmeras versões da teoria estética que vê as artes como uma espécie de escudo de Perseu. Neste escudo miramos os olhos da Górgona que, segundo Primo Levi, matou ou emudeceu aqueles que chegaram ao fundo do sistema concentracionário e se deparam com eles. Para muitos sobreviventes, como é o caso de Jorge Semprun (1994), a pessoa que melhor pode escrever sobre os campos de concentração é quem não esteve lá e lá entrou pelas portas da imaginação ${ }^{4}$.

Mas esta solução está longe de implicar uma pacificação na cena do trauma e do seu testemunho. Antes é por conta da imaginação que muitas acusações são feitas contra o testemunho. Ou seja, antes de se criticar a literatura (com seu evidente compromisso com a imaginação), a própria narrativa testemunhal, que se quer "primeira", atestação, fonte original da realidade, mesmo esta narrativa é descartada por muitos historiadores - como o próprio Raul Hilberg (1996) como sendo fonte não fidedigna para o historiador. Neste ponto vislumbramos uma querela que acompanha a historiografia desde seus primórdios, em sua luta contra a escrita dita imaginativa. Mas ao invés de negarmos ao testemunho a possibilidade de ver na imaginação e em seu trabalho de síntese de imagens um potente aliado, devemos, com Derrida (1998), ver nesta aproximação entre o campo testemunhal e o da imaginação a possibilidade mesma de se repensar tanto a literatura, como o testemunho e o registro da escrita autodenominado de sério e representacionista. Ocorre uma revisão da noção de literatura justamente porque do ponto de vista do testemunho ela passa a ser vista como indissociável da vida, a saber, como tendo um compromisso com o real. Aprendemos ao longo do século XX que todo produto da cultura pode ser lido no seu teor testemunhal. Não se trata da velha concepção realista e naturalista que via na cultura um reflexo da realidade, mas antes de um aprendizado - psicanalítico - da leitura de traços do real no universo cultural. Já o discurso dito sério é tragado e abalado na sua arrogância quando posto diante da impossibilidade de se estabelecer uma fronteira segura entre ele, a imaginação e o discurso dito literário. Não existe uma essência do literário que dê conta de contê-lo diante do discurso dito sério. Por fim, como escreve Derrida, "le témoignage a toujours partie liée avec la possibilité au moins de la fiction, du parjure et du mensonge. Cette possibilité éliminée, aucun témoignage ne serait plus possible et n'aurait plus en tout cas son sens de témoignage" (Derrida, 1998: 28). O testemunho só tem sentido com a sua contraparte estrutural, o falso-testemunho. Ou seja, assim como Coleridge (1817) definiu a literatura como uma suspensão voluntária da desconfiança, o mesmo, em outro grau (mas justamente tudo torna-se uma questão de grau), se dá no 
testemunho. Sem a nossa vontade de escutar, sem o desejo de também portar aquele testemunho que se escuta, não existe o testemunho. $\mathrm{O}$ dialogismo do testemunho o transporta para o campo da pragmática do testemunho. E aqui já estamos anunciando nosso próximo passo: a política do testemunho.

Antes de passar para este item, mas já nos dirigindo a ele, tratemos por fim, dentro do tema das aporias do testemunho, da questão da sua paradoxal singularidade. Todo testemunho é único e insubstituível. Esta singularidade absoluta condiz com a singularidade da sua mensagem. Ele anuncia algo excepcional. Por outro lado, é esta mesma singularidade que vai corroer sua relação com o simbólico. A linguagem é um constructo de generalidades, ela é feita de universais. $\mathrm{O}$ testemunho como evento singular desafia a linguagem e o ouvinte. Sabemos que a fragmentação do real, o colapso do testemunho do mundo, como vimos, emperra sua passagem e tradução para o simbólico. A conhecida literalidade da cena traumática - ou o achatamento de suas imagens, que vimos acima - trava a simbolização. Mas ao se reafirmar esta singularidade absoluta do testemunho barra-se a possibilidade de sua repetição e sinapse com o simbólico, sempre assombrado pela possibilidade da sua ficcionalização. Como vimos, esta passagem para o imaginário é desejável e pode ter um efeito terapêutico, mas para um certo discurso sobre o testemunho - sobretudo o jurídico, mas não só - a ficção contamina e dissolve o teor de verdade do testemunho. No discurso jurídico é onde este elemento paradoxalmente singular do testemunho (e das provas) é levado mais adiante, colocando o testemunho em um verdadeiro território de ninguém. Dostoiévski percebeu isto e, freqüentador contumaz de tribunais, ele dizia que as provas têm sempre "dois gumes" (Dostoiévski, [1865] 2001: 348), um verdadeiro insight psicanalítico sobre o duplo vínculo. Ou seja, a "literalidade" da situação traumática traz consigo a sensação de singularidade absoluta. Esta não é nada mais do que o sintoma da ruptura com o simbólico. Na tentativa de cobrir este gap com a simbolização a testemunha se volta para o trabalho da imaginação. É neste ponto que o campo jurídico passa a lançar uma suspeita sobre o testemunho. Ele gostaria de manter a singularidade total do testemunho, que significaria a chancela de seu teor de "prova", de fragmento do real. Mas a engrenagem jurídica emperra uma segunda vez, justamente ao defender esta singularidade literal do evento. Pois também as leis - como a linguagem - são generalizantes, são universais que muito precariamente cobrem os "delitos" individuais. O testemunho como híbrido de singularidade e de imaginação, como evento que oscila entre a literalidade traumática e a literatura imaginativa, assombra duplamente o direito.

Por outro lado, o testemunho também se quer compreensível e, mesmo, o testemunho se quer exemplar. Neste sentido reencontramos um veio tradicional 
do conceito de testemunho, que o articula à figura cristã do mártir (também muito cara a Dostoiévski). Mártir é aquele que sofre e morre para testemunhar sua fé. O mártir (do grego mártus- uros, aquele que testemunha, ou seja, que percebe o mundo), ao testemunhar de modo único esta fé universal, torna-se ele mesmo um exemplo, um modelo, uma vida exemplar, que as hagiografias até o século XX reproduziam com certo sucesso. Aquele que testemunha um fato excepcional muitas vezes torna-se ele também uma figura exemplar. Sabemos do valor atribuído em nossa sociedade aos sobreviventes. Eles representam exemplos únicos daqueles que viram de perto atrocidades inomináveis. Eles portam estas verdades e são tratados como porta-vozes delas. Esta unicidade paradoxal do testemunho, que desafia a linguagem, levou também ao discurso da unicidade das catástrofes. Em particular fala-se muito da unicidade da Shoah. Como escreveu Primo Levi: "o sistema concentracionário nazista permanece ainda um unicum, em termos quantitativos e qualitativos" (Levi, 1990: 7). Mas esta questão deve ser vista com cautela. Seria moral comparar qual grupo tentativamente dizimado sofreu mais? Aqui encontramos uma típica armadilha de nossa era politicamente correta e devemos, de preferência, não pisar nela e sim tentar desmontá-la.

Do ponto de vista das vítimas - e este ponto de vista é fundamental ao se estudar o testemunho, voltaremos a este ponto - toda catástrofe é única. Radicalizar esta singularidade, assim como condenar toda comparação entre os genocídios, por outro lado, pode gerar uma espécie de teologia negativa concentracionária, muito improdutiva e que apenas tende a reproduzir dois males: em primeiro lugar a própria situação do traumatizado na sua resistência à simbolização e, em segundo lugar, o discurso dos algozes que também visa estender um tabu sobre o discurso que recorde as atrocidades cometidas. Como escreveu Ruth Klüger (1994), ela mesma uma sobrevivente de três campos de concentração e autora de um relato autobiográfico publicado em português com o título Passagens da memória, "mesmo cada cachorro é único" (Klüger, 1994: 70).

\section{Política DA MEMÓRIA}

O testemunho é uma modalidade da memória. Se os estudos sobre o testemunho - no seu sentido não mais religioso ou meramente jurídico, mas antes como uma busca de se ler na cultura as marcas das catástrofes do século XX - se desenvolveram nas últimas décadas é porque ocorreu neste período uma virada culturalista dentro das ditas ciências humanas. Nesta virada a memória passou a ocupar um lugar de destaque, submetendo a quase onipresença da historiografia no que tange à escritura de nosso passado 5 . Neste período também a própria his- 
toriografia se abriu aqui e ali à influência dos discursos da memória, como vemos em trabalhos de história que introduzem procedimentos da história oral ou nos que se abrem também ao trabalho com as imagens. A historiografia positivista tradicional é avessa às imagens, desconfia delas assim como despreza a imaginação. Já a memória sempre foi pensada como um misto de verbalidade e imagens. Em seu pequeno tratado De memoria et reminiscentia (450 a 24) Aristóteles notou que a memória, devido ao seu caráter de arquivo de imagens, pertence à mesma parte da alma que a imaginação: ela é um conjunto de imagens mentais das impressões sensuais, com um adicional temporal; trata-se de um conjunto de imagens de coisas do passado. Aristóteles também escreveu com relação ao nosso pensamento de um modo geral: "a alma nunca pensa sem uma imagem mental" (De anima, 432 a 17, citado por Yates, 1974: 32); "mesmo quando pensamos de modo especulativo, devemos ter uma imagem mental com a qual pensamos" (De anima, 432 a 9, citado por Yates, 1974: 32). Esta idéia é importante de ser destacada ao tratarmos do testemunho, porque assim como falamos de narrativa testemunhal também deve-se pensar em uma arte testemunhal, ou seja, em práticas imagéticas do testemunho ${ }^{6}$.

Por agora nos contentemos em acentuar o elemento eminentemente político no qual se desdobram os discursos testemunhais. $\mathrm{O}$ próprio conceito de testemunho pode ser traçado ao longo do século XX na sua relação com o pensamento político. Jean Norton Cru (citado por Rousseau, 2003), o primeiro a introduzir o conceito no campo da historiografia, tinha como objetivo fazer uma crítica da primeira guerra mundial e dos discursos oficiais, belicistas, que enalteciam as figuras dos heróis guerreiros. Sua resposta foi propor que a historiografia se abrisse para os testemunhos dos soldados. Seu livro Témoins, de 1929, deve ser visto como a primeira tentativa sistemática de se pensar o testemunho moderno ${ }^{7}$.

Já Walter Benjamin (1974), com a sua concepção do historiador como um chiffonier, também abriu a historiografia para o discurso testemunhal, apesar de ter utilizado pouco este conceito. Mas uma frase famosa das suas teses Sobre o conceito da história (Benjamin, 1974), não deixa dúvidas quanto à sua fortíssima proposta de leitura da história na sua face testemunhal. Refiro-me evidentemente à frase: "nunca existiu um documento da cultura que não fosse ao mesmo tempo um [documento] da barbárie" (Benjamin, 1974: 696; tradução nossa). É interessante ler a tradução do próprio Benjamin dessa famosa passagem: "Tout cela [l'héritage culturel] ne témoigne [pas] de la culture sans témoigner, en même temps, de la barbarie”. Já na América Latina, sobretudo desde os anos 1960, o conceito de testemunho adquiriu uma centralidade enorme no contexto da resistência às ditaduras que assolaram o continente. 
Hélène Piralian (2000) escreve seu referido livro de ensaios sobre o genocídio dos armênios de 1915-1916 sob o signo de uma escritura contra o negacionismo. Como muitos de vocês sabem, aquele genocídio que atingiu cerca de 1.200.000 armênios do então Império otomano, de uma população total de cerca de 1.800.0000, até hoje é negado pelo governo da Turquia. Ainda em 2005 um congresso sobre este genocídio, que deveria ocorrer na Universidade de Bogazici, foi impedido de ocorrer pelo governo turco (Folha de São Paulo, 24/09/2005: A27). Para Piralian o desafio do testemunho deste genocídio negado - que assim matou duas vezes suas vítimas e continua a assassiná-las simbolicamente - é o de se construir em termos coletivos espaços para além do desejo da vingança, da parte dos descendentes das vítimas, e com a renúncia da negação, do lado dos turcos. Apenas deste modo ela crê que se poderia finalmente proceder ao trabalho de luto, que até o momento foi travado e impedido por conta da negação. $\mathrm{O}$ negacionismo neste caso é apenas um caso particularmente radical de um movimento que acompanha o gesto genocida. $\mathrm{O}$ genocida sempre visa a total eliminação do grupo inimigo para impedir as narrativas do terror e qualquer possibilidade de vingança. Os algozes sempre procuram também apagar as marcas do seu crime. Esta é uma questão central que assombra o testemunho do sobrevivente em mais de um sentido.

Em primeiro lugar porque o sobrevivente vive o sentimento paradoxal da culpa da sobrevivência. A situação radicalmente outra, na qual todos deveriam morrer, constitui sua origem negativa. A indizibilidade do testemunho ganha com este aspecto um peso inaudito. Mas o negacionismo é também perverso, porque toca no sentimento acima referido de irrealidade da situação vivida. $\mathrm{O}$ negacionista parece coincidir com o sentimento comum que afirma a impossibilidade de algo tão excepcional. $\mathrm{O}$ apagamento dos locais e marcas das atrocidades corresponde àquilo que no imaginário posterior também tende a se afirmar: não foi verdade. A resistência quando se trata de se enfrentar o real parece estar do lado do negacionismo. Este sentimento comum mora no próprio sobrevivente e o tortura, gerando uma visão cindida da realidade. Piralian nota que o testemunho visa a integração do passado traumático. Esta integração só pode ser conquistada contra o negacionismo. Não por acaso se conta que Hitler em um discurso a seus chefes militares em 22 de agosto de 1939, às vésperas da invasão da Polônia, teria dito "Quem se lembra hoje do extermínio dos armênios [durante a Primeira Guerra Mundial]?”. Sua intenção era clara: apenas o lado heróico da guerra seria lembrado, a impunidade estaria garantida. A negação antecedeu o próprio ato, ou seja, a tentativa de extermínio dos judeus europeus. A memória da barbárie tem, portanto, também este momento iluminista: preservar contra o negacionismo, como que em uma admoestação, as imagens de sangue do passado ${ }^{8}$. 
Catherine Coquio (2004), em um interessante livro sobre o genocídio dos Tutsis no Ruanda de 1994, aborda justamente os conflitos entre os rituais oficiais de memória e as tentativas individuais da população sobrevivente de enfrentar este luto quase impossível de 1.300.000 mortos assassinados com facões ao longo de apenas três meses. Ela descreve uma situação na qual enquanto o Estado tendeu para um rápido "trabalho de memória", mais parecido a um trabalho de esquecimento, boa parte da população sofre diante da ausência de interlocutores para suas demandas de testemunho. Os rituais oficiais pareceriam mais Deckerinnerung (memória encobridora) do que real disposição a tratar do passado. Faz parte destes rituais a publicação de um dicionário com o nome dos desaparecidos, a exumação dos cadáveres enterrados em fossas coletivas e a construção de memoriais, como foi o caso do Memorial de Kigali. Este último foi inaugurado em 2004, aos dez anos do massacre, e contém um museu do genocídio, cuja cenografia foi inspirada em Yad-Vasem, o memorial central dedicado à Shoah em Jerusalém. Mas faltam espaços para o testemunho. As igrejas, que poderiam em parte abrigar esta demanda, foram transformadas em 1994 em cenário para os massacres. Um relato de Monique Ilbudo, escrito em 1998, quatro anos após o genocídio, apresenta um pouco o retrato desta população destruída por aquela experiência. "Em 1998 as pessoas ainda estavam embrutecidas, perdidas. Alguns haviam escolhido a loucura para sobreviver e nos contavam coisas incoerentes. Outros estavam fechados no mutismo. Outros ainda andavam como fantasmas, completamente destruídos” (Ilbudo, citada por Coquio, 2004: 83).

Já o testemunho de Esther Mujawayo, também citado por Coquio (2004), mostra um descompasso entre as boas intenções daqueles que querem dar apoio a esta população e suas necessidades.

estes psicólogos... não queriam ouvir nosso traumatismo senão sob a forma que eles o compreendiam. [...] percebíamos que o país se transformava em um campo de experiências de um bando de aventureiros e antes de mais nada, de aprendizes de psicólogo, de engenheiros, médicos. Quantos energúmenos nós não vimos?

[...] a maior parte dos que emprestam fundos e agentes humanitários são pessoas apressadas e, como todas as pessoas apressadas, freqüentemente julgam antes de escutar: eles querem soluções rápidas, eficazes como mecanismos de automóvel, mas que não podem funcionar com humanos, ainda menos com humanos que saem de um genocídio. Eles querem se livrar da sua culpa com programas rápidos (Mujawayo, citada por Coquio, 2004: 84) 
Esther Mujawayo reclama também da retórica oficial de 2004 que afirmava que já se havia falado "o suficiente" do genocídio. Ela vê uma coincidência entre este tipo de idéia e o desejo dos Hutus de esquecer tudo e de apagar o passado. $\mathrm{O}$ Estado assumiu um discurso de unidade nacional, tentando conciliar os desejos dificilmente conjugáveis dos Hutus e dos Tutsis. Deste modo, o testemunho não pôde acontecer e estabelecer sua tentativa de criar pontes entre o sobrevivente e a realidade, entre ele e a sociedade. O discurso ficou estancado. Mesmo as tentativas de introduzir algo semelhante às Comissōes de Verdade e Conciliação da África do Sul parecem não ter obtido o resultado esperado. A introdução da Gacaca, uma instituição jurídica tradicional de Ruanda, uma espécie de conselho popular, deveria ter permitido a confissão em massa dos culpados e o testemunho das vítimas. Como este ritual não previa sanções penais, ele acabou se transformando em um ritual de anistia disfarçado de boas intenções. Neste sentido a Gacaca foi instrumentalizada pelo projeto de reconciliação e unificação que previa o perdão como meio de cura dos traumas sociais. Já a própria ONU tampouco teve bemvinda sua iniciativa de criar um Tribunal Penal Internacional para Ruanda, uma vez que ela é vista como cúmplice por sua inação durante o genocídio.

Jean Hatzfeld (2005) destaca a fala de uma sobrevivente deste genocídio que afirma, dentro de um topos que vimos acima, que não adiantaria testemunhar, porque ninguém acreditaria nos fatos relatados. Sem contar que os sobreviventes têm medo de retaliaçóes contra os que testemunham em público, visto que em 2003 ocorreu uma série de assassinatos de sobreviventes que foram considerados potenciais denunciantes das atrocidades (Coquio, 2004). Lendo o testemunho de Sylvie, uma assistente social de Ruanda citada por Hatzfeld (2005), entendemos um pouco melhor do que se trata nesta luta contra este legado do mal. Percebemos que a justiça e sua capacidade de negociação entre os partidos e entre o passado e o presente ainda pode ter um papel a desempenhar nesta cena, como de resto já está ocorrendo na América Latina em países como a Argentina e o Chile, que também se vêem às voltas com a herança dos gigantescos desmandos ocorridos durante seus regimes ditatoriais. Citemos as palavras de Sylvie:

No fundo de mim mesma não se trata de perdão ou de esquecimento, mas de reconciliação. $\mathrm{O}$ branco que deixou os assassinos agirem, não há nada a lhe perdoar. Quem olhou o vizinho abrir o ventre das moças para matar o bebê diante dos olhos delas, não há nada a perdoar. Não há por que desperdiçar palavras para falar desse assunto com esta gente. Só a justiça pode perdoar... Uma justiça que ofereça um lugar à verdade, para que o medo se esvaia... Um dia, talvez, uma coabitação ou uma ajuda mútua voltem a existir entre as famí- 
lias dos que mataram e dos que foram mortos (Sylvie, citada por Hatzfeld, 2005: 218).

O tema da narração do trauma de catástrofes históricas nos levou, portanto, a passar da cena do testemunho para a cena jurídica. Mas será esta capaz de permitir a construção da desejada passagem entre os indivíduos traumatizados pela catástrofe e a sociedade? Ela permitirá uma reintegração do passado9? Sem dúvidas a esfera do direito e a instituição do tribunal podem criar fóruns para esta construção de passagens e para a refundação de moradias para estes Eus danificados, mas é verdade também que, enquanto um membro da esfera do poder, o direito não está isento de parcialidades. E mais, enquanto um modo de pensar falocêntrico calcado no discurso da comprovação e da atestação, ou seja, do testemunho como testis, o terceiro em uma cena de litígio, e não como superstes, discurso de um sobrevivente, o direito tende a não garantir espaço para a fala muitas vezes fragmentada e plena de reticências do testemunho do trauma (Seligmann-Silva, 2005). Talvez a busca deste local do testemunho seja antes uma errância, um abrir-se para sua assistematicidade, para suas fraturas e silêncios. É na literatura e nas artes onde esta voz poderia ter melhor acolhida, mas seria utópico pensar que a arte e a literatura poderiam, por exemplo, servir de dispositivo testemunhal para populações como as sobreviventes de genocídios ou de ditaduras violentas. Mas isto não implica, tampouco, que nós não devamos nos abrir para os hieróglifos de memória que os artistas nos têm apresentado. Podemos aprender muito com eles.

\section{REFERÊNCIAS BIBLIOGRÁFICAS}

Abraham, N. \& Torok, M. (1995). A casca e o núcleo. São Paulo: Escuta.

Adordo, T. (1973). Notas de literatura. Rio de Janeiro: Tempo Brasileiro.

Agamben, G. (1998). Quel che resta di Auschwitz. L'archivio e il testimone. Torino: Bollati Boringhieri editore.

Antelme, R. (1957). L'espèce humaine. Paris: Gallimard.

Benjamin, W. (1974). Gesammelte Schriften, v. 1. Frankfurt: Suhrkamp.

Coleridge, S. T. (1817). Biographia Literaria. Princeton: Princeton University Press.

Coquio, C. (2004). Rwanda. Le réel et les récits. Paris: Belin.

Cru, J. N. (1929). Témoins. Paris: Ed. Les Etincelles.

Derrida, J. (1998). Demeure. Maurice Blanchot. Paris: Galilée.

Dostoiévski, F. (1865). Crime e castigo. São Paulo: Editora 34, 2001. 
Felman, S. (2002). The juridical unconscious: trials and traumas in the twentieth century.

Boston: Harvard University Press.

Hatzfeld, J. (2005). Uma temporada de facões. Relatos do genocídio em Ruanda. São Paulo: Companhia das Letras.

Hilberg, R. (1996). The politics of memory: the journey of a Holocaust historian. Chicago: Ivan R. Dee Publisher.

Klüger, R. (1994). Weiter leben. Eine Jugend. Frankfurt/M.: DTV.

Laplanche, J. \& Pontalis, J.-B. (1988). Vocabulário da psicanálise. São Paulo: Martins Fontes.

Laub, D. (1995). Truth and testimony: the Process and the struggle. In Caruth, C. (org.).

Trauma. Explorations in memory (pp. 61-75). Baltimore: Johns Hopkins University Press. Levi, P. (1988). É isto um homem. Rio de Janeiro: Rocco.

. (1990). Os afogados e os sobreviventes. Rio de Janeiro: Paz e Terra.

. (1997). A trégua. São Paulo: Companhia das Letras.

. (2005). Rapport sur Auschwitz. Paris: Kimé.

Piralian, H. (2000). Genocidio y transmisión. México/Buenos Aires: Fondo de Cultura.

Rousseau, F. (2003). Le procès des témoins de la Grande Guerre. L'affaire Norton Cru. Paris:

Seuil.

Seligmann-Silva, M. (2003). Reflexões sobre a memória, a história e o esquecimento. In

Seligmann-Silva, M. (org.). História, Memória, Literatura. O testemunho na era das catástrofes (pp. 59-89). Campinas: Editora da UNICAMP.

. (2005). Testemunho e a política da memória: o tempo depois das catástrofes.

Projeto História, no 30, 31-78.

Semprun, J. (1994). L'écriture au la vie. Paris: Gallimard.

Shakespeare, W. (1602). The Tragedy of Hamlet, Prince of Denmark. In Wright, W. A.

The complete works of William Shakespeare (pp. 731-781). New York: Garden City, 1936.

Sófocles. (500BC). Edipo Rey. Santiago: Editorial Universitária, 1982.

Yates, F. A. (1974). Art of memory. Chicago: University of Chicago Press.

\section{Notas}

1 Este paralelo entre a cena do testemunho e a da clínica parece-me importante porque responde em parte à questão acerca da possibilidade do testemunho em meio, e não após as situações traumáticas. O testemunho, na verdade, é marcado pelo tempo do presente. Trata-se também sempre de uma performance testemunhal. $\mathrm{O}$ ato de testemunhar tem o seu valor em si, para além do valor documental ou comunicativo deste evento. A cena do testemunho, se 
o testemunho de fato acontece, é sempre e paradoxalmente externa e interna ao evento narrado. Interna porque em certo sentido não existe um "depois" absoluto da cena traumática, já que esta justamente é caracterizada por uma perenidade insuperável. Por outro lado, o testemunho é externo àquela cena traumática na medida em que ele cria um local meta-reflexivo. Ele exige um certo distanciamento. Assim, poder testemunhar durante uma situação traumática, como a vida no Lager, o soldado no campo de batalhas, ou o morador de zonas de conflito bélico e social (com todas as características particulares de cada uma destas situaçôes), poder testemunhar já implica uma saída (mesmo que apenas simbólica) desta situação. O testemunho em si é terapêutico. Os diários de guerra e de prisioneiros e muitos documentos testemunhais encontrados enterrados no Lager são prova desta atividade testemunhal mesmo em situações aparentemente impossíveis de abrigarem um espaço testemunhal. Os testemunhos recolhidos por M. V. Bill no seu filme Falcão - Meninos do tráfico (2006) e analisados por Ana Maria Rudge e Betty Fuks durante o Encontro Nacional Trauma e Memória (organizado pelo Programa de Pós-Graduação em Psicologia Clínica da PUC-Rio em junho de 2007, ocasião na qual este trabalho foi também apresentado), também são uma prova contundente deste fato.

2 No final de $A$ trégua Primo Levi (1997) narra um sonho que o perseguiu após seu retorno de Auschwitz que também expressa esta força da realidade do Lager de dissolver tudo aquilo que poderíamos denominar de seu "exterior". Trata-se de um sonho em cascata: Primo Levi vê-se entre familiares e amigos, à mesa ou em outro local aprazível. Aos poucos ele é tomado de uma angústia difusa, "tudo desmorona e se desfaz ao meu redor, o cenário, as paredes, as pessoas, e a angústia se torna mais intensa e mais precisa. Tudo agora tornou-se caos: estou só no centro de um nada turvo e cinzento. E, de repente, sei o que isso significa, e sei também que nada era verdadeiro fora do Lager. De resto eram férias breves, o engano dos sentidos, um sonho: a família, a natureza em flor, a casa. Agora esse sonho interno, o sonho de paz, terminou, e no sonho externo, que prossegue gélido, ouço ressoar uma voz, bastante conhecida; uma única palavra, não imperiosa, aliás breve e obediente. É o comando do amanhecer em Auschwitz, uma palavra estrangeira, temida e esperada: levantem, "Wstavach" (Levi, 1997: 359). A realidade "externa" torna-se a exceção, tempo de "férias", imagem de "sonho". Ela fica sitiada pelo real do Lager, que é descrito como sonho-pesadelo que engloba e devora o mundo exterior. O despertar final de $A$ trégua - comandado por uma voz conhecida e estrangeira (Heimlich totalmente Unheimlich) - é o despertar para esta terrível verdade do trauma. Jorge Semprun (1994) narra este mesmo sonho em cascata em seu livro-testemunho L'écriture au la vie.

3 Também uma passagem de uma entrevista de Primo Levi, na qual ele responde ao famoso dictum adorniano segundo o qual escrever poesia após Auschwitz seria um ato de barbárie: "A minha experiência prova o contrário. Pareceu-me, então, que a poesia era melhor mesmo do que a prosa para exprimir o que me oprimia. Quando eu digo 'poesia' eu não penso em nada

Psic. Clin., Rio De Janeiro, vol.20, N.1, P.65 - 82, 2008 
lírico. Nesta época eu teria reformulado a frase de Adorno: depois de Auschwitz não se pode escrever poesia senão sobre Auschwitz" (Levi, 2005: 34). De fato, o próprio Adorno reformulou aquele dictum alguns anos depois em um sentido próximo ao de Levi. Como ele escreveu em 1962 em seu trabalho Engagement, também referindo-se ao seu dictum de 1949: "O excesso de sofrimento real não permite esquecimento; a palavra teológica de Pascal 'on ne doit plus dormir' deve-se secularizar. [...] aquele sofrimento [...] requer também a permanência da arte que pró́be" (Adorno, 1973: 64). No mesmo passo lemos ainda: "não há quase outro lugar [senão na arte] em que o sofrimento encontre a sua própria voz" (Idem).

4 Neste sentido ele fez um largo elogio da imaginação como meio de "suscitar a imaginação do inimaginável” (Semprun, 1994: 135).

5 Com relação a este ponto remeto ao meu ensaio de 2003.

6 Refiro-me aqui a um importante filão na arte contemporânea no qual encontramos artistas que praticam uma nova "arte da memória". Entre os artistas que trabalham de modo programático o tema da memória podemos destacar Rosangela Rennó, Anselm Kiefer, Joseph Beuys, o cartunista Art Spiegelman (autor de Maus e de In the Shadow of no Towers), os cineastas Alain Resnais (autor de Nouit et Brouillard e de Hiroshima mon Amour), Claude Lanzmann (autor de Shoah), Chris Marker (autor de La Jetée), Wim Wenders, o artista Jochen Gerz (autor de antimonumentos, como seu Monumento contra o fascismo, em Hamburgo ou o Memorial contra o racismo, de Saarbrücken), Christian Boltanski (autor, entre outras obras centrais, de The Missing House, em Berlim), Horst Hoheisel (também autor de antimonumentos, como de uma proposta de se explodir o portal de Brandenburgo como memorial para lembrar a Shoah, autor de Os portōes dos alemães, e co-autor, ao lado de Anfreas Knitz, da exposição Vogel Frei - Pássaro Livre, realizada na Pinacoteca de São Paulo em 2003). Podemos lembrar também de outros artistas que se dedicaram especificamente em algumas de suas obras ao tema da representação da Shoah, como Naomi Teresa Salomon (lembremos de sua exposição Asservate - Exibits, Auschwitz, Buchenwald, Yad Vashem no Schirn Kunsthalle de Frankfurt em 1995) e de Zbigniew Libera (autor da polêmica obra Lego Concentration Camp Set, de 1996). Na Argentina vemos também um boom da memória deslanchado pelo trabalho de luto da última ditadura, que deixou como legado mórbido mais de 30.000 desaparecidos. Entre estes artistas eu destacaria dois fotógrafos: Marcelo Brodsky e Helen Zout.

7 Com relação ao papel de Jean Norton Cru na história do conceito de testemunho ver o livro de Frédéric Rousseau (2003) e o meu artigo de 2005.

8 Se existe de um lado o negacionismo, como uma prática tradicional dos autores de crimes e sobretudo dos autores coletivos de crimes contra a humanidade, e, do outro lado, a tendência do sobrevivente e da vítima a querer se "esquecer" do seu passado traumático, podemos distinguir ainda uma terceira modalidade de resistência ao real que seria a marca de nossa atual sociedade caracterizada pela presença traumatizante da violência. Em Freud a teoria da defesa diante da "vivência da dor" contém, neste sentido, ensinamentos preciosos. O mesmo 
vale para seu conceito de Verleugnung, recusa da realidade. Vale lembrar de uma passagem do dicionário de Laplanche \& Pontalis (1988) ao tratar deste último termo: "Na medida em que a recusa incide na realidade exterior, Freud vê nela, em oposição ao recalcamento, o primeiro momento da psicose: enquanto o neurótico começa por recalcar as exigências do id, o psicótico começa por recusar a realidade" (Laplanche \& Pontalis, 1988: 562).

9 Shoshana Felman apostou nesta possibilidade de o testemunho jurídico criar um espaço para o testemunho em seu belo livro de ensaios de 2002.

Recebido em 28 de novembro de 2007 Aceito para publicação em 17 de fevereiro de 2008 